\title{
Materials Science, Instrument Knowledge, and the Power Source Renaissance
}

\author{
By Matthew N. Eisler
}

\section{INTRODUCTION}

What do the tools of an interdiscipline look like? For users of consumer electronics and vehicles powered by advanced batteries, this question may be of more than academic interest, particularly as it relates to cost and safety of the lithium-ion battery. Power source technoscience progressed slowly for most of the 20th century, owing mainly to the intellectual stagnation of electrochemistry, the science traditionally associated with batteries, following the overshadowing of its energy storage and conversion applications by petroleum-based systems from the $1920 \mathrm{~s}^{1}$ This relative intellectual torpor lasted until the last quarter of the 20th century, when electrochemistry began to revive under the influence of solidstate ionics, a materials science given impetus by the energy and environmental crises. The main fruit of this disciplinary convergence was the lithium-ion rechargeable, as important an enabler of mobile computing as the scaled microprocessor. If materials science helped revive electrochemistry and power source technoscience, however, the commercial lithium-ion battery raised wholly new challenges of fundamental knowledge that extant instruments and tools were not necessarily well-suited to address. ${ }^{2}$

\section{MATERIALS, SOCIETY, AND THE DECLINE OF ELECTROCHEMISTRY}

Understanding this problem begs comparison between materials development in electronics and power sources. These fields should properly be regarded as allied, but for a host of reasons have existed at great social and intellectual

${ }^{1}$ R. H. Schallenberg, Bottled Energy: Electrical Engineering and the Evolution of Chemical Energy Storage. Philadelphia, PA, USA: American Philosophical Society, 1982, pp. 391-392.

${ }^{2}$ Putting the singular nature of these developments in context, one electrochemist noted that it had taken two centuries to achieve a fivefold increase in the energy density of all batteries but only a quarter century to double lithium-ion power; see J.-M. Tarascon, "The li-ion battery: 25 years of exciting and enriching experiences," Interface, vol. 25, no. 3, pp. 79-83, 2016.

Digital Object Identifier: 10.1109/JPROC.2017.2770439

distance from each other. Brock and Lécuyer's ideas of the interplay of material and social agency in the context of solid-state electronics and the silicon gate transistor (what they refer to as material and competitive/market "logics," respectively) suggest an important commonality. Their observation that actors perceived the material as the device is equally if not more apt in the context of the electrochemical cell, a worldview that has had important consequences for scaling and systems integration. ${ }^{3}$

In most other respects, however, the material "logics" of the silicon semiconductor do not easily map out onto batteries. There is no exact parallel of a single, standardized material. To be sure, some battery materials have predominated in particular applications, such as lead-acid in the auxiliary automobile functions of starting and lighting. Most contemporary portable consumer electronics use lithium-ion rechargeable batteries, as do many electric vehicles, although these applications generally use different variant chemistries. Nickel metal hydride remains an important battery chemistry for use in hybrid electric cars. Nor has there been a trend in exponential scaling of components and performance in the manner of "Moore's Law." In the words of Koonin, a former undersecretary for the U.S. Department of Energy, it is simply easier to shift bytes

${ }^{3}$ D. C. Brock and C. Lécuyer, "Digital foundations: The making of silicon gate manufacturing technology," Technol. Culture, vol. 53, pp. 561-597, Jul. 2012; C. Lécuyer and D. C. Brock, "The materiality of microelectronics," History Technol., vol. 22, no. 3, pp. 301-325, Sep. 2006. 
than molecules. ${ }^{4}$ In such observations there is an admission that the physical obduracy of battery materials is somehow qualitatively different than semiconductor materials.

Social barriers also played an important role in retarding electrochemistry. The federal government's mobilization of fossil fuel automobility during World War I and Fordism's postwar triumph made it impossible for electric vehicles to compete on cost in most applications. For decades afterwards, enthusiasm for battery research in the United States waned. ${ }^{5}$ During the Cold War, only federal institutions were willing to procure powerful new batteries, mainly for specialized military applications. And in the early Cold War years, power source technoscience lay primarily in the realm of materials science and engineering. An interdisciplinary field built around ceramics, metallurgy, structural and inorganic chemistry, and, above all, solid-state physics, materials science and engineering was stimulated by the national security state in the hope of yielding advanced materials for use in computers, missiles, and spacecraft. ${ }^{6}$

\section{INSTRUMENT PRACTICE IN AN ADOPTED FIELD}

Supplementing electrochemistry with materials sciences and engineering in the power source field had important consequences for the ways researchers communicated with each other and used instruments and tools. When historians consider instruments, they tend to focus on single devices generative of canonical science knowledge, with "big science" enterprises involving telescope and particle accelerator technology attracting particular attention. ${ }^{7}$

4"Sustainability and maintaining US competitiveness: A presentation by Under Secretary Steven Koonin, June 25, 2010.” http://science. energy.gov/s-4/speeches-and-presentations/?p=1

${ }^{5} \mathrm{G}$. Mom, The Electric Vehicle: Technology and Expectations in the Automobile Age. Baltimore, MD, USA: Johns Hopkins Univ. Press, 2004, pp. 238-241.

${ }^{6}$ W. O. Baker, "Advances in Materials Research and Development," in Advancing Materials Research, P. A. Psaras, and H. D. Langford, Eds. Washington, DC, USA: National Academy Press, 1987, pp. 3-22.

${ }^{7}$ See, for example, D. O. Edge and M. Mulkay, Astronomy Transformed: The Emergence of Radio Astronomy in Britain. New York, NY, USA: Wiley, 1976; R. W. Smith, The Space Telescope: A Study of NASA, Science, Technology, and Politics. Cambridge, U.K.: Cambridge Univ. Press, 1989; H. Collins and T. Pinch, "A New Window On The Universe: The NonDetection of Gravitational Radiation" in The Golem: What Everyone Should Know About Science. Cambridge, U.K.: Cambridge Univ. Press, pp. 91-108, 1993; P. Galison and B. Hevly, Eds. Big Science: The Growth of Large-Scale Research. Stanford, CA, USA: Stanford Univ. Press, 1992; C. Westfall, "Retooling for the future: Launching the advanced light source at Lawrence's Laboratory, 1980-1986" Historical Studies in the Natural Sciences, vol. 38, no. 4, pp. 569-609, 2008; W. P. McCray, Giant Telescopes: Astronomical Ambition and the Promise of Technology. Cambridge, MA, USA: Harvard Univ. Press, 2006; R. P. Crease, "Recombinant science: The birth of the relativistic heavy ion collider (RHIC)," Historical Studies in the Natural Sciences, vol. 38, no. 4, pp. 535-568, 2008; L. Hoddeson, A. W. Kolb, and C. Westfall, Fermilab: Physics, the Frontier, and Megascience. Chicago, IL, USA: Univ. Chicago Press, 2008; P. Doing, Velvet Revolution at the Synchrotron: Biology, Physics, and Change in Science. Cambridge, MA, USA: MIT Press, 2009; M. Riordan, L. Hoddeson, and A. W. Kolb, Tunnel Visions: The Rise and Fall of the Superconducting Super Collider. Chicago, IL, USA: Univ. Chicago Press, 2015.
In materials science and engineering, no one instrument or tool dominates. Moreover, conditions sometimes arose in this interdiscipline that complicated conventional definition of instruments. At the nanoscale, the distinction between experimental conditions (which includes instruments) and unknown or vaguely known objects of investigation can collapse. ${ }^{8}$ As practitioners studied materials in ever-smaller increments, moreover, the instruments themselves sometimes gave rise to physical phenomena and could themselves become objects of research. Scholars refer to such effects as "instrument knowledge." 9

Institutional factors also conditioned instrument knowledge in materials science and engineering. Along with biotechnology and information technology, materials science and engineering may be seen as one of the science-based postindustrial enterprises emerging from around the 1960s in which research, development, and manufacturing were dispersed. ${ }^{10}$ In this era of smaller, decentralized science, instrumentation could emerge from many quarters by actors who did not necessarily identify as instruments makers. ${ }^{11}$

The corollary is that materials and agglomerations of materials could also be conceived of as instruments or research tools. Convergence of instrument and object of research has been observed in the development of solidstate electronics and the silicon gate transistor. In that context, scientific instruments were transformed into semiconductor production tools and actors understood silicon semiconducting materials as devices. ${ }^{12}$

Similar dynamics are present in solid-state power source innovation. But there are important differences. An advanced battery industry did not emerge until the early 1990s, so the feedback between research, development, and manufacturing so generative of tools in the electronics sector has begun only relatively

${ }^{8}$ See C. C. M. Mody and M. Lynch, "Test objects and other epistemic things: A history of a nanoscale object," British J. History Sci., vol. 43, no. 3, pp. 423-458, 2010; A. Nordmann, "Molecular Disjunctions," in D. Baird, A. Nordmann, and J. Schummer, Eds. Discovering the Nanoscale. Amsterdam, The Netherlands: IOS Press, 2004, pp. 51-62.

${ }^{9}$ A. Marcovich and T. Shinn, "How scientific research instruments change: A century of Nobel Prize physics instrumentation," Social Sci. Inf., vol. 56, no. 3, pp. 348-374, 2017.

${ }^{10}$ See D. Bell, "Foreword 1999," in The Coming of Post-Industrial Society: A Venture in Social Forecasting. New York, NY, USA: Basic Books, 1999, pp. xxxiv-xliv.

${ }^{11}$ B. Joerges and T. Shinn, "A Fresh Look at Instrumentation: An Introduction," in Instrumentation Between Science, State, and Industry. Dordrecht, The Netherlands: Kluwer, 2001, p. 10.

${ }^{12}$ See C. Lécuyer and D. C. Brock, "From nuclear physics to semiconductor manufacturing: The making of ion implantation," History Technol., vol. 25, no. 3, pp. 193-217, 2009; D. C. Brock and C. Lécuyer, "Digital foundations: The making of silicon gate manufacturing technology," Technol. Culture, vol. 53, pp. 561-597, Jul. 2012; C. Lécuyer and D. C. Brock, "The materiality of microelectronics," History Technol., vol. 22, no. 3, pp. 301-325, Sep. 2006. 
recently. ${ }^{13}$ Hence, the gulf between test and real-world environments that characterizes many fields has been appreciably larger in the power source space. ${ }^{14}$ Here, paradoxically, instrument knowledge was both eclectic and siloed. Advanced power source technoscience was constituted out of many different fields by practitioners using an array of tools and instruments who, for institutional reasons, were often alienated from each other.

This problem became especially apparent when researchers attempted to build practical power sources. Predicting how reactions and side reactions would unfold over time became increasingly difficult as electrodes and cells were scaled into batteries and integrated into applications, a problem made worse by the longstanding estrangement of power source engineering from electronics engineering.

So while materials sciences and engineering helped revive power source technoscience, its tools and instruments were sometimes hard-pressed to address new problems arising from commercialization. The story of how key figures in the lithium battery revolution including John B. Goodenough, M. Stanley Whittingham, and others produced instrument knowledge from research through manufacturing illuminates the challenges of innovation in the power source space.

\section{DEVICE AS INSTRUMENT: ORIGINS OF SOLID-STATE IONICS}

In accounts of materials sciences, X-ray diffraction figures as the classic instrument, and it was no less vital in the discovery of compounds central to the lithium-ion battery. ${ }^{15}$ For Goodenough (Fig. 1), a solid-state physicist and inventor or coinventor of several of the most important of these materials, X-ray diffraction (Fig. 2) was the "principal tool" for determining structure in the early 1950s, at the outset of his career. ${ }^{16}$

However, Goodenough rejected suggestions that instrumentation determined his research trajectory. His access to

\footnotetext{
${ }^{13}$ The term "advanced power source" generally refers to batteries that are rechargeable, powerful (defined as the rate of energy flow per unit of volume), and energetic (defined as the amount of stored energy per unit of volume or mass). Batteries are often considered advanced if they have energy densities greater than $30-40 \mathrm{~W} \cdot \mathrm{h} / \mathrm{kg}$, the contemporary limits of classical battery chemistries such as lead-acid and nickelcadmium. Notable advanced power sources include sodium-sulfur, lithium-titanium disulfide, sodium-metal chloride, and lithiumaluminum-metal sulfide batteries, as well as a range of fuel cells; see C.-X. Zu and H. Li, "Thermodynamic analysis on energy densities of batteries," Energy Environ. Sci., vol. 4, pp. 2614-2624, 2011 (on p. 2615).

${ }^{14}$ T. Pinch, “'Testing-one, two, three...testing!' Toward a sociology of testing," Sci. Technol. Human Values, vol. 18, no. 1, pp. 27-31, 1993.

${ }^{15} \mathrm{~B}$. Bensaude-Vincent holds that the application of X-ray diffraction in the 1910s to help visualize the arrangement of atoms in crystalline structures was the "prime mover" in the formation of solid-state physics and its concern with investigating "structure-sensitive properties" of crystals; see "The construction of a discipline: Materials science in the United States," Historical Studies Phys. Biol. Sci., vol. 31, no. 2, pp. 224-225, 2001.

${ }^{16} \mathrm{~J}$. B. Goodenough, interview by B. Bensaude-Vincent and A. Hessenbruch, Mar. 2001, Caltech Library, http://authors.library. caltech.edu/5456/1/hrst.mit.edu/hrs/materials/public/Goodenough/ Goodenough_interview.htm (accessed Jan. 28, 2015).
}

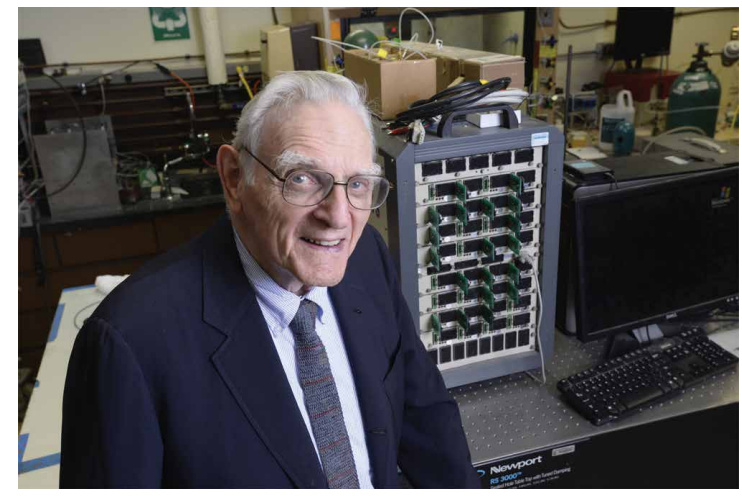

Fig. 1. John Goodenough in his lab in 2015 (courtesy of the University of Texas at Austin).

instruments varied according to the nature of a given collaboration. Much more important to him were tools that enabled him to fabricate his own materials. Most important of all was the freedom to determine the research agenda. ${ }^{17} \mathrm{In}$ his early career, that freedom stemmed from Goodenough's success in exploiting the redundancy of Lincoln Laboratory, a federal defense science installation set up at MIT by the Air Force in 1951, after it had completed its primary mission. ${ }^{18}$ As a young researcher in Project Lincoln, the effort to develop the computer for the Semi-Automatic Ground Environment air defense system, Goodenough distinguished himself in his study of the properties of ceramic materials.

When Project Lincoln ended in 1957-1958, most of its researchers were let go. But Goodenough managed to stay on, inheriting control of the laboratory's ceramics lab. In addition to a powder X-ray diffractometer, this facility was equipped with fabrication equipment including high-temperature furnaces, a chemical hood, and hand press tools. ${ }^{19}$

For nearly a decade, Goodenough was able to use these tools without concern for externally imposed research "targets." 20 By the late 1960s and early 1970s, however, shifting political conditions compelled publicly funded

\footnotetext{
${ }^{17}$ In his 2001 interview with Bensaude-Vincent and Hessenbruch,
} Goodenough repeatedly rejected this line of questioning from Hessenbruch; Goodenough, interview by Bensaude-Vincent and Hessenbruch.

${ }^{18}$ Historians often note the doctrinal incoherence faced by statefinanced academic-based mission institutions after fulfilling their original missions in the early Cold War period; for an account of this phenomenon at Lincoln Laboratory, see R. Slayton, "From a 'Dead Albatross' to Lincoln Labs: Applied research and the making of a normal Cold War university," Historical Studies Natural Sci., vol. 42, no. 4, pp. 255-282, 2012; see also M. A. Dennis, “'Our first line of defense:' Two University Laboratories in the postwar American state," Isis, vol. 85, no. 3, pp. 427-455, 1994; S. W. Leslie, The Cold War and American Science: The Military-Industrial-Academic Complex at MIT and Stanford. New York, NY, USA: Columbia Univ. Press, 1993; K. C. Redmond and T. M. Smith, From Whirlwind to MITRE: The R\&D Story of the SAGE Air Defense Computer. Cambridge, MA, USA: MIT Press, 2000.

${ }^{19}$ Goodenough, interview by Bensaude-Vincent and Hessenbruch.

${ }^{20} \mathrm{~J}$. B. Goodenough, interview by the author, Austin, TX, USA, Jul. 11, 2013. 


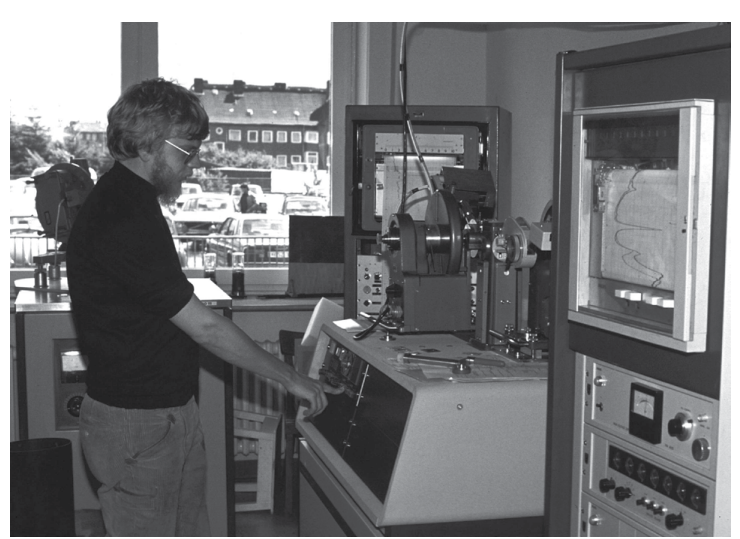

Fig. 2. X-ray diffractometer Philips PW1050 at the GeologicalPaleontological Institute, Kiel; user: Prof. Dr. Dietmar Schenk (by Hannes Grobe/AWI, via Wikimedia Commons).

science to take on an increasingly applied character. In response to the Mansfield Amendment's prohibition of military funding of academic basic research and the emergence of the energy and environmental crises as major public policy concerns, Goodenough became interested in energy storage and conversion devices.

Throughout his life, to be sure, the solid-state physicist remained motivated primarily by materials design and basic questions of solid-state science. Still, Goodenough derived problems (or "engineering targets," as he referred to them) from devices. And these became the basis of experiments he designed for chemists to execute. Batteries and battery components can, hence, be seen as kinds of tools used in the co-construction of materials science and modern electrochemistry. One such tool, the sodium-sulfur battery, yielded an important vein of engineering targets. It was a product of the Ford Motor Company's Scientific Laboratory, invented in the mid-1960s by J. T. Kummer and N. Weber [Fig 3(a) and (b)]. These researchers inverted the usual arrangement of battery materials. Normally, battery electrodes are solid, but in the new device they were liquid, or rather, molten. For the electrolyte, the solvent in which charge carriers of an electrochemical cell are dissolved, the scientists chose a solid ceramic known as beta-alumina. ${ }^{21}$ Beta-alumina had hitherto been used mainly as industrial furnace insulation. When applied in a power source, however, this prosaic substance also proved an efficient ion conductor.

As a power source, the sodium-sulfur battery was impractical owing to its high operating temperature and volatile materials, which caused corrosion and durability and safety problems. Nevertheless, the device and its components, especially beta-alumina, stimulated study of the reversible insertion of ions inside solids, a major shift in

\footnotetext{
${ }^{21}$ N. Weber and J. T. Kummer, "Sodium-sulfur secondary batteries," in Proc. 21st Annu. Power Sources Conf., vol. 21, pp. 37-39, 1967.
}

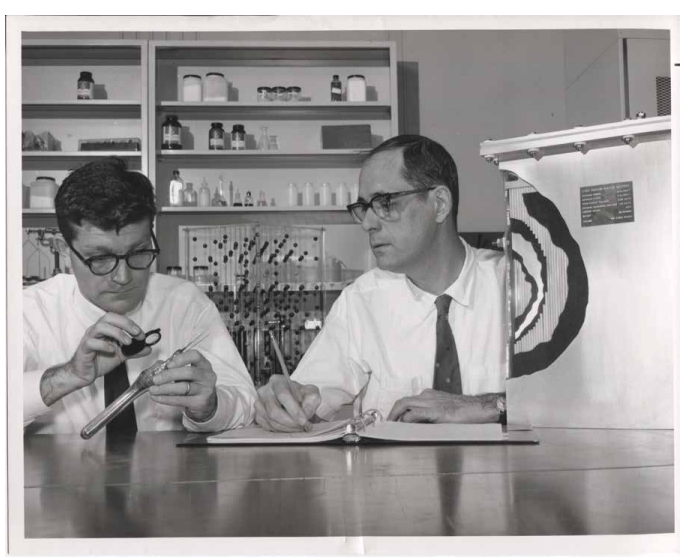

(a)

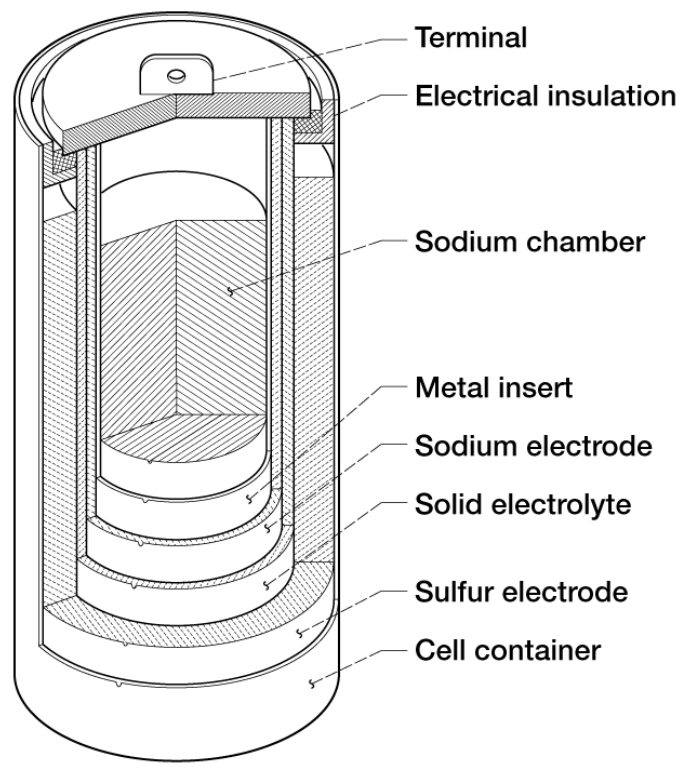

(b)

Fig. 3. (a) Dr. N. Weber (left) and Dr. J. T. Kummer (photo courtesy of Ford Motor Company, Science Service Collection, Division of Work \& Industry, National Museum of American History, Smithsonian Institution). (b) A sodium-sulfur battery.

thinking at a time when electrochemists believed that reactions occurred primarily on electrode surfaces in relation to liquid electrolytes. ${ }^{22}$

Much of this work was blue-sky materials research. Kummer and his Ford Scientific Laboratory colleague Y.-F. Yu Yao used a powder X-ray diffractometer to characterize the structure of beta-alumina and also employed a crystal scintillation detector to count the diffusion coefficient of sodium ions using radioactive isotopes of the

${ }^{22}$ H. Arribart and B. Bensaude-Vincent, "Beta-Alumina," Feb. 16, 2001, Caltech Library, http://authors.library.caltech.edu/5456/1/hrst. mit.edu/hrs/materials/public/Beta-alumina.htm (accessed Aug. 12, 2013). 
diffusing ions. ${ }^{23}$ For his part, Goodenough credited his role in investigating sodium-sulfur technology with helping bring about the blending of solid-state physics with electrochemistry, creating the new field of solid-state ionics. ${ }^{24}$

\section{INSTRUMENTS OF AN INTERDISCIPLINE}

Practitioners of the emerging interdiscipline used an eclectic array of existing and emerging tools. Solid-state materials characterization instruments such as nuclear magnetic resonance began to be used in power source research and development, exploiting the electronic and magnetic properties of ions in solids. And as electrodes, electrochemical cells, and batteries became both tool and object of solidstate ionics, so did the toolkit of the electrochemist become relevant to solid-state researchers. Foremost among these was the potentiostat. This relatively simple bench-top instrument was invented by the electrochemist A. Hickling at University College, Leicester, U.K., in 1941 to measure and control voltage in an electrochemical cell. Interested primarily in electrolysis, Hickling noted that the device had numerous applications. ${ }^{25}$ Together with the galvanostat, a variant used to control current, the potentiostat became a standard tool for fundamental studies of electrochemistry and electrophysiology, potentially allied fields that, like electronics and power sources, were socially alienated from one other. $^{26}$

In 1970s and 1980s, Goodenough's chief engineering targets were supplied by the lithium-titanium disulfide battery. Another milestone in solid-state power source technoscience, this device was invented by the chemist M. S. Whittingham in the laboratories of Exxon Research and Engineering. A product of concerns that the energy crisis might force automakers to commercialize electric vehicles, the technology operated on the principle of the insertion and extraction of lithium ions (a process known as intercalation) from layered sulfides. ${ }^{27}$ To understand the rate of lithium diffusion, Whittingham employed data from a colleague who had used nuclear magnetic resonance technology (in what was claimed as one of the first applications of the technology on lithium compounds) to measure the magnetic interaction between lithium ions and these

${ }^{23}$ Y.-F. Yu Yao and J. T. Kummer, "Ion exchange properties of and rates of ionic diffusion in beta-alumina," J. Inorganic Nuclear Chem., vol. 29, pp. 2454-2455, 1967.

${ }^{24} \mathrm{~J}$. B. Goodenough, interview by the author, Austin, TX, USA, Jul. 11, 2013.

${ }^{25}$ A. Hickling, "Studies in electrode polarisation. Part IV-The automatic control of the potential of a working electrode," Trans. Faraday Soc., vol. 28, pp. 27-33, 1942.

${ }^{26}$ J. E. Harrar, "The Potentiostat and the voltage clamp," Interface, vol. 22, no. 4, pp. 42-44, Winter 2013. According to Harrar, a similar device known as the "voltage clamp" was independently invented by University of Chicago researcher K. Cole in the late 1940s.

${ }^{27} \mathrm{M}$. S. Whittingham, "Electrical energy storage and intercalation chemistry," Science (New Series), vol. 192, no. 4244, pp. 1126-1127, Jun. 11, 1976. host structures and the resulting change in the electronic properties of these structures. ${ }^{28}$ Like the sodium-sulfur battery, the titanium disulfide battery proved impractical as a power source. Whittingham had focused on the cathode, pairing it with an interim test anode made of metallic lithium, a dangerous combination when the cell was subject to repeated recharging. ${ }^{29}$

For Goodenough, however, titanium-sulfide chemistry posed interesting problems. By then he was the chair of Oxford University's Inorganic Chemistry Laboratory, having decamped Lincoln Laboratory in 1976 following the federal government's transfer of all of his solid-state research to the Energy Research and Development Administration as part of its ongoing consolidation of energy research and development. Besides safety, the key issue for Goodenough was power. A layered sulfide cathode mated to a metallic lithium anode could yield no more than $2.5 \mathrm{~V}$, and using a safer anode would have lower voltage still further. Goodenough believed metal oxides offered superior performance as a host structure for lithium ions. ${ }^{30}$

Thusly motivated, he and a team of researchers proceeded to develop the lithium-cobalt-oxide cathode. A landmark event in power source technoscience, this project illustrated the convergence of the tools of solid-state materials research, chemistry, and electrochemistry. Goodenough's team used X-ray photography and ethylenediaminetetraacetic acid (EDTA) to characterize a sample of the material. Then they tested a lithium-cobalt-oxide cathode in a potentiostat setup in a vacuum glove box; to complete the circuit, the researchers initially paired the cathode to a "counter" electrode made of lithium metal. It yielded an astounding $4 \mathrm{~V}$. Indeed, the very reactivity that made these materials attractive as a power source complicated instrument analysis. So high was the voltage that it threatened to decompose the electrolyte. The team opted for less reactive lithium-vanadium-bronze counter and reference electrodes to lower the voltage. They used coulometry, a set of techniques of analytical chemistry to understand the transformation of matter in electrolysis reactions, determining that lithium ions could be reversibly removed from the cathode. And they employed X-ray powder diffractometry to confirm that lithium and cobalt had been ordered into the stable layers necessary to host lithium ions. ${ }^{31}$

Goodenough's team did not invent a practical battery, as a suitable anode remained to be developed. From 1985,

\footnotetext{
${ }^{28}$ See B. G. Silbernagel, "Lithium intercalation complexes of layered transition metal dichalcogenides: An NMR survey of physical properties," Solid State Commun., vol. 17, pp. 361-365, 1975.

${ }^{29}$ J. B. Goodenough, "Rechargeable batteries: Challenges old and new," J. Solid State Electrochem., vol. 16, no. 6, pp. 2019-2029, 2012 (on p. 2022); J. B. Goodenough and Y. Kim, "Challenges for rechargeable Li batteries," Chem. Mater. Rev., vol. 22, no. 3, pp. 587-603, 2010 (on p. 592).

${ }^{30} \mathrm{~J}$. B. Goodenough, interview by the author, Austin, TX, USA, Jul. 11, 2013.

${ }^{31}$ K. Mizushima, P. C. Jones, P. J. Wiseman, and J. B. Goodenough, " $\mathrm{Li}_{\mathrm{x}} \mathrm{CoO}_{2}$ : A new cathode material for batteries of high energy density," Mater. Res. Bull., vol. 15, no. 6, pp. 785-786, 1980.
} 
Sony's Energytec division worked to integrate lithium with a safe graphitic anode in a project to replace the nickel-cadmium battery in consumer electronics that owed a good deal to the contributions of the Asahi Kasei Corporation and Akira Yoshino. ${ }^{32}$ Sony succeeded in commercializing the lithium-cobalt-oxide battery in 1991, initially for use in its portable telephone. ${ }^{33}$ The results would revolutionize consumer electronics, but create new problems for practitioners that would require new tools, techniques, and instruments.

\section{BATTERIES AND SURFACE SCIENCE}

In essence, the commercialization of the lithium-ion battery signaled a rebirth of electrochemistry. For decades, the energy density of most rechargeables had hovered around $25 \mathrm{~W} \cdot \mathrm{h} / \mathrm{kg}$. Sony's first-generation lithium-cobalt-oxide battery yielded $80 \mathrm{~W} \cdot \mathrm{h} / \mathrm{kg}$, more than tripling the historical mean, and by 2001 the company had further boosted that to $165 \mathrm{~W} \cdot \mathrm{h} / \mathrm{kg} .{ }^{34}$ By 2011 , some lithium-ion chemistries produced $210 \mathrm{~W} \cdot \mathrm{h} / \mathrm{kg}$, and some sources claimed that certain formulas gave more than $250 \mathrm{~W} \cdot \mathrm{h} / \mathrm{kg}$. ${ }^{35}$

The power source renaissance in turn heralded the arrival of a new "high technology" manufacturing enterprise. Like other such enterprises, battery manufacturing involved the production of complex and volatile materials that were easily contaminated and required extremely clean and controlled production environments. Devices made from these materials had to be fabricated to very high tolerances. ${ }^{36}$

And integrating battery manufacturing with the existing industries that supplied battery applications placed new demands on instruments and tools. The initial drive to innovate lithium-ion batteries had stemmed from the power and energy requirements of mobile electronics using increasingly powerful microprocessors. In the realm of consumer electronics, designers assumed that lithium cells only had to last as long as the devices they powered, which was on the order of a few years. ${ }^{37}$

Batteries for electric vehicles, on the other hand, had to last much longer. Accordingly, they had to be manufactured to higher standards, imposing new demands on diagnostic and production equipment. In one sense, battery technologists were better equipped than ever to meet these

\footnotetext{
${ }^{32}$ Y. Nishi, "My Way to Lithium-Ion Batteries," and M. Yoshio, A. Kozawa, and R. J. Brodd, "Introduction: Development of Lithium-Ion Batteries," in Lithium-Ion Batteries: Science and Technologies. New York, NY, USA: Springer-Verlag, 2009, pp. v-vii, xvii-xxvi.

${ }^{33} \mathrm{~K}$. Ozawa, "Lithium-ion rechargeable batteries with $\mathrm{LiCoO}_{2}$ and carbon electrodes: The $\mathrm{LiCoO}_{2} / \mathrm{C}$ system," Solid State Ionics, vol. 69, no. 3-4, pp. 212-221, 1994 (on p. 212).

${ }^{34}$ Y. Nishi, "Lithium ion secondary batteries: Past 10 years and the future," J. Power Sources, vol. 100, no. 1-2, pp. 101-106, 2001 (on p. 104).

${ }^{35} \mathrm{C}$.-X. $\mathrm{Zu}$ and H. Li, "Thermodynamic analysis on energy densities of batteries," Energy Environ. Sci., vol. 4, pp. 2614-2624, 2011 (on p. 2615).

${ }^{36}$ C. Lécuyer and D. C. Brock, "High tech manufacturing," History Technol., vol. 25, no. 3, p. 167, 2009.

${ }^{37}$ M. G. Pecht, "Editorial: Re-thinking reliability," IEEE Trans. Compon. Packag. Technol., vol. 29, no. 4, pp. 893-894, Dec. 2006.
}

challenges, because the commercialization of lithium-ion power coincided with the golden age of materials science instrument technology. From the late 1980s, a host of new instruments and techniques capable of engaging phenomenon in situ became available. Probe microscopes and highresolution transmission electron microscopes, augmented by ever-increasing computational power, enabled great strides in materials development and characterization. One variant of probe microscopy known as the scanning electrochemical microscope (SECM) would play a major role in fundamental research of power source materials. Invented in the late 1980s by A. J. Bard, a colleague of Goodenough's at the University of Texas at Austin, the SECM represents an important example of the convergence of materials science with electrochemistry. ${ }^{38}$

Of particular significance for commercial lithium-ion batteries were surface analysis instruments like X-ray photoelectron spectroscopy and infrared spectroscopy. They were crucial in characterizing a structure essential to battery lifetime known as the solid electrolyte interphase (SEI), a layer of decomposed solvents, salts, lithium ions, and impurities from the electrolyte that formed on the graphite anode mainly in first charge cycle. Ideally, these materials completely coated the anode and provided electronic insulation, enabling ionic conductivity and intercalation while preventing decomposition of electrolyte and loss of lithium ions and power density. In the years following the discovery of the SEI layer in 1979, researchers became aware that this structure was vital to lithium battery performance, and expended considerable energy developing charge-discharge protocols and additives that promoted its proper formation. ${ }^{39}$ In this and other efforts to understand and increase the lifespan of lithium-ion batteries for electric vehicles the federal government played an important role, notably through the U.S. Department of Energy's Advanced Technology Development program, launched in $1998 .^{40}$ By the late 2000s, the question of how SEI layers formed in the five or so major lithium-ion chemistries then on or nearing the marketplace had become of crucial significance to battery manufacturing. ${ }^{41}$

\footnotetext{
${ }^{38}$ A. J. Bard, F.-R. F. Fan, J. Kwak, and O. Lev, "Scanning electrochemical microscopy: Introduction and principles," Analytical Chem. vol. 61, no. 2, pp. 132-138, 1989; L. H. Clippards, "Chemist Al Bard Receives National Medal of Science," News from the College of Natura Sciences, Jan. 2, 2013, The University of Texas at Austin; https://cns. utexas.edu/news/bard-national-medal-of-science, accessed Oct. 23, 2017.

${ }^{39}$ S. J. An, J. Li, C. Daniel, D. Mohanty, S. Nagpure, and D. L. Wood III, "The state of understanding of the lithium-ion-battery graphite solid electrolyte interphase (SEI) and its relationship to formation cycling," Carbon, vol. 105, pp. 52-76, 2016.

${ }^{40}$ R. A. Sutula, Progress Report for the Advanced Technology Development Program. Washington, DC, USA: U.S. Dept. Energy, 2000.

${ }^{41}$ K. L. Gering and J. J. Einerson, "Statistical Design of Experiment for Li-ion Cell Formation Parameters using "Gen3". Electrode Materials Final Summary," DOE-EERE Merit Review Meeting, May 19, 2009, in 2009 DOE Hydrogen Program and Vehicle Technologies Program Annual Merit Review and Peer Evaluation Meeting, May 18-22, 2009, Washington, DC, USA; https://energy.gov/sites/prod/files/2014/03/f13/ esp_03_gering.pdf, accessed Mar. 3, 2017.
} 


\section{PIONEERING AN INDUSTRY}

Producing advanced batteries at scale for electric vehicles was no easy task. The experience of one manager illustrates the challenges of integrating the instruments, tools, and techniques of the fledgling science of solid-state electrochemistry into the automobile industry, a sector with virtually no experience of advanced battery technology. In 2009, J. Johnson took charge of a \$200 million Obama Administration stimulus project to develop battery production at Johnson Controls sufficient for 80000 automobiles a year. A materials scientist with some 12 years of experience at the company, Johnson held bachelor of science degrees in technology and mechanical engineering technology. In the automobile industry, he recalled, "a lot of people just don't get an electrochemistry degree."

Johnson's job was to scale laboratory production of five or six cells a day to three a minute, and do to this in compliance with automotive manufacturing and quality standards such as ISO/TS 16949 and Ford's Advanced Product Quality Planning. A protocol for advanced batteries did not then exist, so one had to be developed from scratch. In consumer electronics, batteries were designed to last three to four years, a lifetime entailing some 400 charge-discharge cycles. Batteries for electric vehicles, however, had to last up to ten years and 2500 cycles.

And that meant that new methods of predicting quality and performance over this timespan had to be developed. Before manufacturing could begin, an arduous regimen of accelerated lifetime testing had to play out, involving up to eight months of constant charging and discharging of cells in thermally controlled chambers.

Fabrication called for finicky quality control and sophisticated production tools and instruments (Fig. 4). Whereas producers of electronics commodity cells sought to weed out defective cells at the end of the manufacturing process

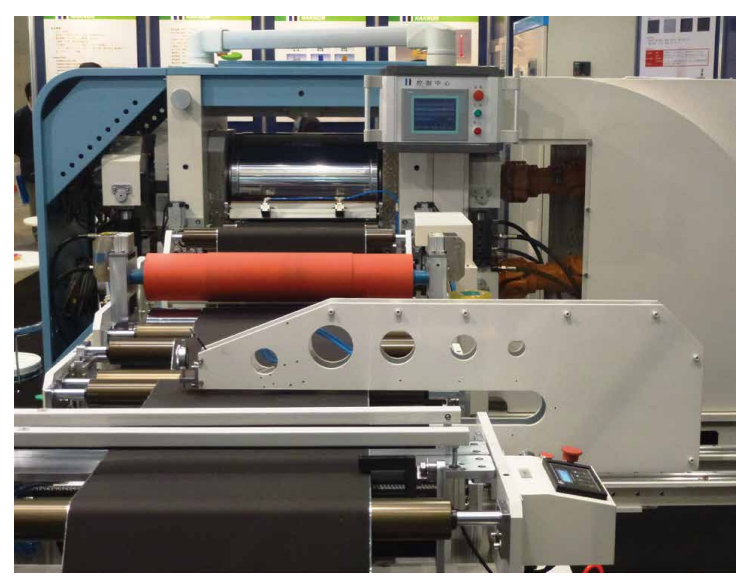

Fig. 4. Calander (pressing) machine for lithium-ion battery electrode manufacturing (by Rudolfsimon, via Wikimedia Commons). to keep costs low, makers of advanced batteries for electric vehicles sought to prevent defects and contamination. Production began when electrode materials were mixed into a slurry and coated, simultaneously and uniformly, onto both sides of a current-collecting foil. This meter-wide sheet was then floated in a full flotation drier that transported the web between rollers $30 \mathrm{~m}$ apart. At Johnson Controls, improvisation was sometimes necessary. Borrowing ideas from high-speed newsprinting technology, the company built a $\$ 20$ million machine to run sheets of foil, containing the process within an extremely dry cleanroom $\left(-40^{\circ}\right.$ dewpoint) to prevent moisture and particles more than half a micrometer in diameter from contaminating the product. Sheets of anode, cathode, and separator polymer, a crucial safety material insulating the electrodes, were then brought together on a high-speed winder. It was, recalled Johnson, "the most complex machine I've ever worked on." The winder pulled the sheets together, through dozens of points of adjustment monitored and controlled with vision technology, to a tolerance of $300-400 \mu \mathrm{m}$. The next step was cell assembly. Cells were cut out of the composite sheet with lasers and placed into battery casings, filled with electrolyte under vacuum pressure, and laser-welded shut. Gas chromatographs were used to run helium leak tests to ensure the cells were hermetically sealed. ${ }^{42}$

Finally, thousands of finished cells underwent formation cycling and testing to eliminate those with manufacturing defects. Such processes called for extremely precise voltage and capacity measurements, illustrating how the dramatic increase in battery performance and knowledge of materials morphology drove instrument technology. In lead-acid batteries, measurements to within a tenth of a volt were long considered acceptable because this did not represent much energy density. In a lithium-ion battery, however, tenths of a volt represented very significant energy density, with important implications for how the SEI layer formed. Accordingly, potentiostats and chargers had to be capable of accuracy to within thousandths of a volt. ${ }^{43}$

Many of these processes were more akin to process chemistry than standard automotive parts manufacturing. Indeed, proponents of battery electric vehicles often claim simplicity as an important quality of the technology in relation to heat-engine propulsion, usually in reference to numbers of moving parts. But battery production, held Johnson, was anything but straightforward. Quality control involved hundreds of thousands of line items of failure modes and effects analysis. Manufacturing complexity, he believed, was actually greater for advanced batteries than for internal combustion engine technology.

\footnotetext{
${ }^{42}$ For a discussion of manufacturing processes of different battery form factors, see K. Tagawa and R. J. Brodd, "Chapter 8: Production Processes for Fabrication of Lithium-Ion Batteries," in Lithium-Ion Batteries: Science and Technologies, M. Yoshio, R. J. Brodd, and A. Kozawa, Eds. New York, NY, USA: Springer-Verlag, 2009, pp. 181-194.

${ }^{43}$ J. Johnson, interview with the author, Jan. 26, 2017.
} 
VIII. WAGES OF SUCCESS: POWER SOURCE INSTRUMENT KNOWLEDGE AND THE FUTURE

The revolution in materials science had helped beget the revolution in power sources technoscience. In some respects, however, the knowledge problems of the commercial lithium-ion battery outpaced the capabilities of the tools of materials science. Proving battery lifetime was especially difficult. The problem with empirical testing regimes, held a group of battery researchers at Dalhousie University, was that they approximated neither the way electric vehicles were driven in real-world circumstances nor battery behavior over time. Electrolyte and charged electrode materials constantly undergo parasitic reactions whether batteries are being cycled or not. One instrument solution, they believed, was the ultrahigh-precision charger, a device that used highrate cycling to "beat the clock" on problematic side reactions. Pioneered by Dalhousie and Kyoto Universities, the technology was transferred to instrument manufacturers in the 2010s, a classic example of how academic research and development sometimes addressed innovation in niche fields that established industry had hitherto ignored. ${ }^{44}$

As such, the case was exemplary of the nascent state of high tech battery manufacturing. But there were limits to the ability of tools and instruments to solve problems in this context. Most in situ instruments were not well suited to characterizing how fully integrated batteries aged over time because they were invasive, aging and damaging the device in the act of investigating it. ${ }^{45}$

${ }^{44}$ J. R. Dahn, J. C. Burns, and D. A. Stevens, "Importance of Coulombic efficiency measurements in R\&D efforts to obtain long-lived li-ion batteries," Interface, vol. 25, no. 3, pp. 75-78, 2016.

${ }^{45}$ C. A. Lundgren, K. Xu, T. R. Jow, J. Allen, and S. S. Zhang, "LithiumIon Batteries and Materials," in Springer Handbook of Electrochemical Energy, C. Breitkopf, K. Swider-Lyons, Eds. Dordrecht, The Netherlands: Springer-Verlag, 2017, p. 471, 473, and 474. In 2015, one group of researchers held that the question of how characterization methods contributed to cell degradation was barely discussed in current literature; see N. Lohmann, P. Wesskamp, P. Haussmann, J. Melbert, and T. Musch, "Electrochemical impedance spectroscopy for lithium-ion cells: Test equipment and procedures for aging and fast characterization in time and frequency domain," J. Power Sources, vol. 273, p. 614, 2015.
Economic pressures, moreover, created technical problems that instrumentation alone could not resolve. Fierce competition led Japanese manufacturers of lithium-ion batteries to shift production to South Korea and China in the early 2000s in operations that, as industry insiders observed, were initially characterized by extensive bugs and high cell scrap rates. ${ }^{46}$ The trend toward offshoring and outsourcing compromised quality control, but it also helped further alienate the disciplines of power electronics and power source research and development. Lax manufacturing protocols and problematic systems integration of lithium-ion batteries with appliances have been implicated in periodic and increasingly serious consumer product crises, with the recall of Sony notebook batteries in 2006 and the Samsung Galaxy Note 7 in 2016 being only the best-known of these. ${ }^{47}$

Electric vehicle battery manufacturing faced different sorts of economic pressures relating to the question of battery ownership, one that has been obscured by the U.S. federal government's subsidization of battery and electric vehicle production. Quite apart from how industrial policy would unfold in the era of the Trump Administration, the problem of how to reconcile the cost, reliability, and safety of lithium power for electric traction is likely to be a key driver of solid-state ionics and electrochemistry for the foreseeable future, ensuring that this sector is the chief locus of innovation of the instruments and tools of power source technoscience.

\section{ABOUT THE AUTHOR}

Matthew N. Eisler is a Strathclyde Chancellor's Fellow and Lecturer in History at Strathclyde University. He studies the relationship between energy and environmental politics and practices of contemporary science, technology, and engineering, especially as they relate to materials sciences, energy conversion technology, and postindustrial industry more generally. Dr. Eisler is currently working on his second book, a study of the industry and culture of electric automobile technology.

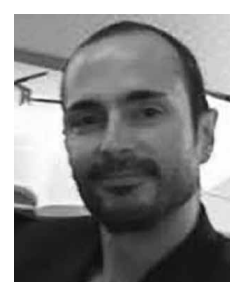

\footnotetext{
${ }^{46}$ D. MacArthur, G. Blomgren, and R. A. Powers, Lithium and Lithium Ion Batteries, 2000: A Review and Analysis of Technical, Market and Commercial Developments. Westlake, OH, USA: Robert A. Powers Assoc., 2000, pp. 17-18.

${ }^{47}$ See M. N. Eisler, "Exploding the black box: Personal computing, the notebook battery crisis, and postindustrial systems thinking," Technol. Culture, vol. 58, no. 2, pp. 368-391, 2017.
} 